\title{
Assessment of tree species diversity and above-ground biomass in two disturbed tropical dry evergreen forests of Coromandel coast of India
}

\author{
Elumalai Pandian* \\ Department of Molecular Analytics, Institute of Bioinformatics, Saveetha School of \\ Engineering, Saveetha Institute of Medical and Technical Sciences (SIMATS), Thandalam, \\ Chennai- 602105 (Tamil Nadu), India \\ Narayanaswamy Parthasarathy \\ Department of Ecology \& Environmental Sciences, Pondicherry University, Puducherry, India \\ Balaraman Tamil Selvan \\ PG \& Research Department of Botany, Pachaiyappa's College, Chennai, 600030 (Tamil Nadu), \\ India \\ ${ }^{*}$ Corresponding author. Email: pandianmaha11@gmail.com
}

\section{Article Info}

https://doi.org/10.31018/

jans.v13i3.2832

Received: July 6, 2021

Revised: August 26, 2021

Accepted: August 29, 2021

\section{How to Cite}

Pandian, E. et al. (2021). Assessment of tree species diversity and above-ground biomass in two disturbed tropical dry evergreen forests of Coromandel coast of India. Journal of Applied and Natural Science, 13(3), 981 - 992. https:// doi.org/10.31018/jans.v13i3.2832

\begin{abstract}
The tree diversity and carbon stock of all woody plants were determined in two-hectare square plots $(100 \mathrm{~m} \times 100 \mathrm{~m})$, established in Suryanpet (SP) and Velleripet (VP) as tropical dry evergreen forest (TDEF) sites on the Coromandel coast of peninsular India. All trees $\geq 10 \mathrm{~cm}$ girth at breast height measured at $1.3 \mathrm{~m}$ from the rooting point were enumerated. A total of $35 \mathrm{tree}$ species ( $\geq 10 \mathrm{~cm}$ gbh) belonging to 34 genera and 23 families were recorded in tropical dry evergreen forests. Tree species richness in 27 (dominant species Dimorphocalyx glabellus Thw.) and 18 (dominant species Strychnos nux-vomica L.) in SP and VP respectively. A total density of woody plants are 671 and 1154 individuals in SP and VP respectively. Tree basal area was greater in site VP (45.46 m2 ha-1) compare the site SP (40.70 m2 ha-1). Most abundant families were Loganiaceae, Euphorbiaceae and Rutaceae and their family index values (FIV) were 56.14, 39.12 and 21.40 , respectively. The above-ground biomass (AGB) of trees totaled in site SP $\left(405.3 \mathrm{Mg} \mathrm{ha}^{-1}\right)$ and VP $\left(721.3 \mathrm{Mg} \mathrm{ha}^{-1}\right)$. The extent of tree species diversity and estimated carbon stock of the TDEF sites will provide the baseline data on the floristic structure and diversity of these forest sites for better management and conservation.
\end{abstract}

Keywords: Allometric equation, Anthropogenic pressure, Biomass, TDEFs, Wood specific density

\section{INTRODUCTION}

Tropical forest provides numerous goods and ecosystem services such as conservation of species, preventing soil erosion, and preserving habitat for plants and animals (Naidu and Kumar, 2016; Armenteras et al., 2009; Pandian and Ravichandran, 2020). Globally, biodiversity is decreasing unexpectedly due to habitat destruction, overexploitation, pollution (Pragasan and Parthasarathy, 2010) as a result of natural forests is occurring in fragments and in degraded forms inflicting a lot of spatial and temporal variation in species richness, composition and productiveness at local and regional levels. Anthropogenic disturbances regularly lead to altered environmental conditions that lead to species diversity destruction in a forest community (Osuri et al.,
2020; Sapkota et al., 2010). Among the diverse forest types, tropical forests are one of the most significant sinks of carbon as they represent as much as $40 \%$ of the carbon stored as terrestrial biomass (Raha et al., 2020; Phillips et al., 1998). Tropical forests spread around $7-10 \%$ of the worldwide land area. However, it represents $34 \%$ of the terrestrial primary productivity (Lewis et al., 2013; Slik et al., 2015). Tropical forests play an important role in the global carbon balance, biodiversity protection, and several other valuable environmental services. Notwithstanding, the carbon stocks of tropical forests are poorly measured in developing countries. The studies remain poorly understood because of the lack of atmospheric monitoring in the tropics (Raha et al., 2020; Kaul et al., 2010; Reichstein et al., 2013). 
Forests are important carbon pools that continuously exchange $\mathrm{CO}_{2}$ with biological system. Indeed, tropical forest ecosystems can hold massive quantities of carbon than the other forest biomes (Vivek and Parthasarathy, 2015; Metz et al., 2001). Tropical forests contain about 40 percent of the total terrestrial carbon stock (Dixon et al., 1994); however, uncertainty prevails in their quantitative contribution to the international carbon cycle (Chave et al., 2005). Above and belowground biomass stocked as carbon in woody plants is impacted directly by anthropogenic disturbances. Deforestation presently represents about $18 \%$ of the international carbon emissions (Vivek and Parthasarathy, 2015). Several major factors, including selective logging, forest fragmentation, and transferring cultivation, play an important role in altering forest biomass (Houghton, 2005). Under the existing scenario of global environmental change and increasing rate of deforestation, it has become important to quantify the carbon stocks in the tropics. However, the direct evaluation of biomass through destructive sampling will probably give a better estimation of forest carbon stocks. It could also be approached using generalized allometric equations (Brown, 1997; Chave et al., 2005) using variables like diameter, height, and wood specific density. Gibson et al. (2011) revealed a global meta-analysis that indicates tropical forest disturbance on biodiversity was more extreme in Asia than in Africa, South America and Central America. Globally, forest ecosystems are threatened by various human activities linked with over usage of forest resources and area encroachment for agriculture, settlement and economic development (Iftekhar and Hoque, 2005; Pandian and Ravichandran, 2019). Tropical dry evergreen forests are short-statured, large-
Iy three-layered, tree-dominated, closed canopy forest type, which is distributed along the Coromandel coast of peninsular India, composed of indigenous species, are mainly sacred groves preserved as a result of the religious belief of the local community (Parthasarathy et al., 2008; Anbarashan and Parthasarathy, 2012; Pandian and Parthasarathy, 2016b). The expanding interest in the land area for human-related activities has increased the stress on these forests over the decade (Pandian, 2015). Tropical dry evergreen forest (TDEF) forests bordering are threatened by the increasing human population, leading to shrinkage in TDEF land areas and increasing forest resource extraction and grazing pressure. Hence, it is of prime importance to estimate the diversity and carbon stocking potential of TDEF ecosystem for conservation with scientific data. The main objective of the present study was to investigate tree population and above-ground biomass (AGB) in two tropical dry evergreen forests of the Coromandel coast of India.

\section{MATERIALS AND METHODS}

\section{Study area}

The present work was carried out in two tropical dry evergreen forest sites (Suryanpet - SP and Velleripet VP) on the Coromandel coast of peninsular India (Fig.1). Suryanpet (11.73329 N and $79.63897 \mathrm{E}$ ) is located $41 \mathrm{~km}$ south of Puducherry and the forest area covers around 2.7 ha. The forest is dominated by $D i-$ morphocalyx glabellus and soil is red ferralitic. Velleripet $(11.7386 \mathrm{~N}$ and $79.6944 \mathrm{E})$ is situated $29 \mathrm{~km}$ west of Villupuram, Tamil Nadu, and establishes a twolayered forest with a normal height of $8 \mathrm{~m}$ forest area

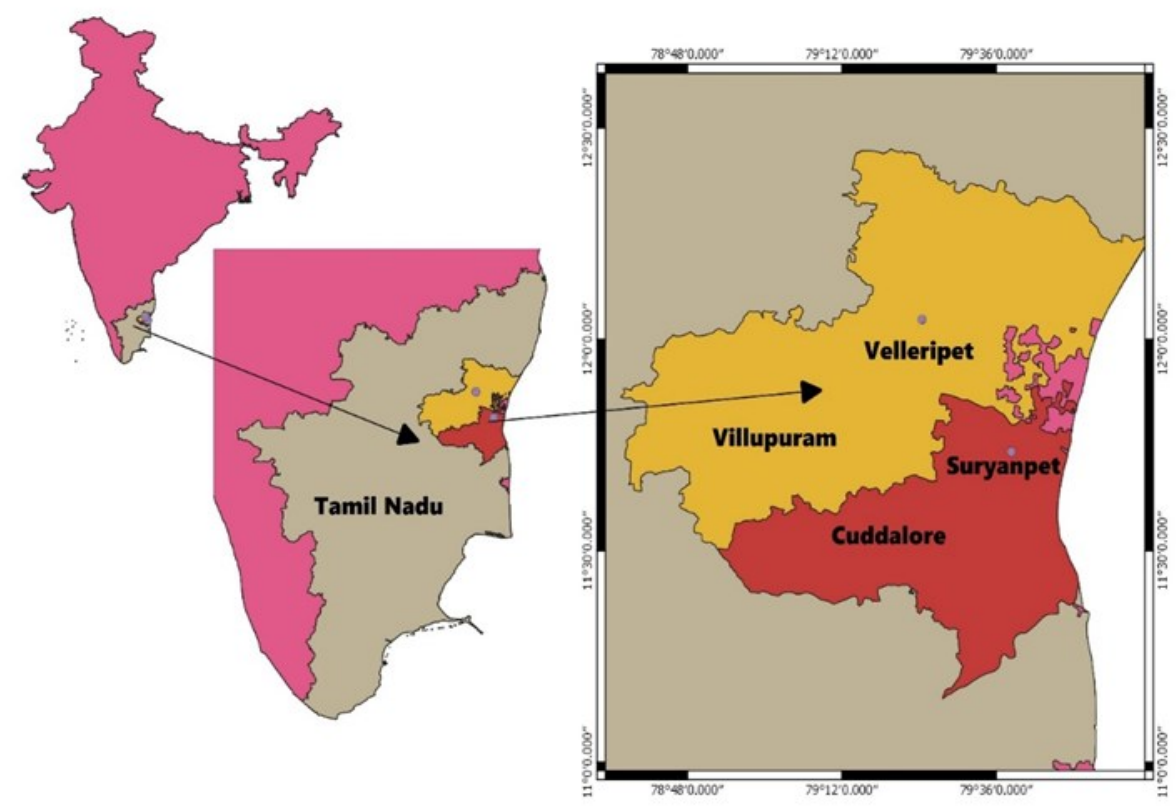

Fig. 1. Map showing the location of two tropical dry evergreen forest sites (Velleripet - VP and Suryanpet - SP) on the Coromandel coast of India. 
around 2 ha and the predominant tree species is $S$ Strychnos nux-vomica. Both the sites under the anthropogenic activities such as forest encroachment for expansion of temple structures, forest resource removal (fodder, firewood, medicinal plants, timber, etc.) and the impact of temple visitors by way of cooking inside the forest during festive occasions and solid waste dumping (polythene, glass bottles). Moreover, both the sites are surrounded by Agricultural fields such as paddy, groundnut, sugarcane, and Cashew plantation. Soils are basically red ferralitic.

\section{Data collection and data analysis}

Two 1-ha plots $(100 \times 100 \mathrm{~m})$ were established and each plot was again divided into one-hundred $10 \mathrm{~m} \times$ $10 \mathrm{~m}$ quadrats for tree assessment. All trees $\geq 10 \mathrm{~cm}$ girth at breast height and measured from (at $1.3 \mathrm{~m}$ ) ground level. For multi-tree stemmed, bole girth was documented separately, basal area was calculated and summed. The extent of the human disturbance was estimated for sites SP and VP. Site disturbance was measured based on human activities such as firewood collection, forest resource removal (fodder, firewood, medicinal plants, timber, etc.), the impact of temple visitors (polythene and glass bottles), grazing by cattle and goats, temple construction and the cultural attachment (local people) by way of cooking inside the forest during festive occasions. The cattle and goat browsing degree was very high in site SP because of nearby human settlements and agricultural fields. In the case of the site VP there is no evidence of cattle and goat browsing. Forest resource removal in the form of the firewood collection and timber extraction is high in site $\mathrm{SP}$. All the sub-classes in various types of disturbance were ranked into relatively low (1), medium (2), and high (3) levels of disturbance (Table 1). The sum of all scores for each site provides an overall ranking of anthropogenic disturbance in the forest. High ranks signify high levels of anthropogenic activities and low ranks low levels of activities.

Site encroachment like temple construction, birdle path use is medium in both sites. Temple visitor's impact scored in low. Tree diversity was assessed using two common species diversity indices: the Shannon index (which combines species richness and evenness into a single value) and the Simpson index (which gives more weight to the abundance of the most common species) were computed following Magurran (2004). (Shannon, $\mathrm{H}^{\prime}=-\sum \mathrm{pi}$ In pi, where pi is the proportion of $\mathrm{i}^{\text {th }}$ species; Simpson, $D=1-\sum$ ni $(n i-1) / N(N-1)$, where ni is the proportion of $i^{\text {th }}$ species and $N$ is the total number of individuals). Species-area curve was raised based on species increment by the sequential arrangement of every 0.1 ha area. Paired t-tests in SPSS software was used to test differences of density $(\geq 10 \mathrm{~cm})$, species richness and basal area among vegetation types. After the collection, data assessment was done for the aboveground biomass for using regression equation given by Chave et al., (2005): AGB est $=\rho \times \exp (-1.499+2.148$ $\ln (D)+0.207(\ln (D))^{2}-0.0281(\ln (D))^{3}$ where, $\rho$ is

Table 1. Present site disturbance score status (1- ranked as rare: 2- occasional: 3- frequent) of two study sites Velleripet (VP) and Suryanpet (SP).

\begin{tabular}{|c|c|c|c|}
\hline No. & Attributes & VP & SP \\
\hline \multirow[t]{3}{*}{1} & Forest encroachment (land use within the forest) & & \\
\hline & i. temple construction & 2 & 1 \\
\hline & ii. forest encroachment & 1 & 1 \\
\hline 2 & Bridle path use & 2 & 2 \\
\hline \multirow[t]{4}{*}{3} & Temple visitors' impact: area used for & & \\
\hline & i. vehicle parking (area occupied) & 2 & 1 \\
\hline & ii. cooking & 1 & 2 \\
\hline & iii. festive occasion use & 3 & 2 \\
\hline 4 & Grazing (cattle/goat) & 3 & 2 \\
\hline 5 & Culture attachment of local people & 2 & 2 \\
\hline \multirow[t]{3}{*}{6} & Resource removal & & \\
\hline & i. fuel wood & 2 & 3 \\
\hline & ii. other: medicinal plants, edible fruits and soil & 2 & 2 \\
\hline 7 & Approach road to temple (width) & 1 & 1 \\
\hline 8 & Fodder collection & 3 & 1 \\
\hline \multirow[t]{2}{*}{9} & Solid waste dumping (plastic, polythene, glass, rexin) & 2 & 3 \\
\hline & Total score & 26 & 22 \\
\hline
\end{tabular}


Table 2. Summary of tree diversity inventory $(\geq 10 \mathrm{~cm}$ gbh) in two tropical dry evergreen forest sites (Velleripet - VP and Suryanpet - SP) on the Coromandel coast of India.

\begin{tabular}{lll}
\hline Variable & SP & VP \\
\hline Species richness & 27 & 18 \\
Number of genera & 25 & 17 \\
Number of families & 18 & 13 \\
Shannon & 2.13 & 1.24 \\
Simpson & 4.78 & 2.15 \\
Fisher's & 5.66 & 3.03 \\
Stand density (stem ha-1) & 671 & 1154 \\
Stand basal area (m2ha-1) & 40.7089 & 45.4621 \\
Above ground biomass (Mg ha-1) & 405.363 & 721.333 \\
Carbon sequestered (Mg ha-1) & 202.681 & 360.667 \\
Number of multi-stemmed trees & 118 & 96 \\
Maximum tree gbh (cm) & 365 & 387 \\
\hline
\end{tabular}

wood specific gravity and $D$ is diameter at breast height.

\section{RESULTS}

A total of 35 tree species ( $\geq 10 \mathrm{~cm}$ gbh) belonging to 34 genera and 23 families were recorded in two 1 -ha plots of tropical dry evergreen forests. There was significant in species richness $(\mathrm{df}=99, \mathrm{P}<0.05)$, density $(\mathrm{df}=99$, $P<0.05)$ and basal area $(\mathrm{df}=99, \mathrm{P}<0.05)$ between the two tropical dry evergreen forest sites. Tree species richness was low (18 species from 13 families) in the moderately disturbed site VP, and site SP harboured 27 tree species from 18 families recorded in site VP (Table 2). The total density of woody plants was 671 and 1154 individuals in SP and VP, respectively. The basal area of trees in the two study sites SP $\left(40.71 \mathrm{~m}^{2}\right.$ $\left.\mathrm{ha}^{-1}\right)$ and VP $\left(45.46 \mathrm{~m}^{2} \mathrm{ha}^{-1}\right)$. The above-ground biomass (AGB) of trees totalled in site SP (405.3 Mg ha-1) and VP $\left(721.3 \mathrm{Mg} \mathrm{ha}^{-1}\right)$. The species diversity indices were greater for SP than VP. Shannon index value was 2.13 and 1.24 in sites SP and VP, respectively. Simpson index is 4.78 and 2.15 in sites SP and VP, respectively (Table 2). A positive correlation was revealed in density $\left(R^{2}=0.5842\right)$ and above-ground biomass $\left(R^{2}=\right.$ 0.8574 ) with disturbance scores (Fig. 7a and b).

\section{Species and family composition}

Total 35 tree species were recorded and 10 species were common in both sites (Table 3). The most abundant tree species are S. nux-vomica (768 individuals), Atalantia monophylla (129 individuals), Lepisanthes tetraphylla (86 individuals) in site VP and $D$. glabellus (263 individuals), L. tetraphylla (117 individual), and Glycosmis pentaphylla (84 individual) occurred in SP. Seventeen tree species were exclusive to site SP which were totally absent in VP and nine species were exclusive to site VP (Table 3). One individual's tree species are Aglaia elaeagnoidea, Drypetes sepiaria, Ficus benghalensis, Dolichandrone falcata and Morinda coreia in both the sites. The contribution of 23 plant families and stand density varied between the two sites. Loganiaceae contributed only one genus and one species, but the density (768 individuals) of the family was very high than the other families, followed by Euphorbiaceae (473 individuals) and Rutaceae (237 individuals), contributing to high density but low in diversity. The Meliaceae, Rutaceae and Mimosaceae (represe nted by 3 genera and three species each) are taxonomically diverse and constituted the most- speciose family (Table 4). The Moraceae with two genera and three species formed the second most species-rich family in both sites. Two genera and two species each represented Euphorbiaceae, Rubiaceae, Cordiaceae, and Verbenaceae. The other families were represented by one genus and one species each. Fifteen families were common to both the sites. Based on FIV the top families include Loganiaceae (65.14), Euphorbiaceae (43.12), Moraceae (25.42), Meliaceae (22.81) and Rutaceae (21.40) (Table 4).

\section{Tree density and basal area by girth classes}

Overall, no distinct difference in stem distribution size class was evident in the two forests. Tree density of girth class distribution consistently decreased with increasing size class of trees from 10 to $210 \mathrm{~cm}$ gbh, except for the greatest girth class $\geq 210 \mathrm{~cm}$ (Fig 3). Basal area of girth class distribution consistently increased with increasing size class of trees from 10 to $210 \mathrm{~cm}$ gbh, except for the girth class $\geq 121$ to $150 \mathrm{~cm}$ in both sites. The lowest size class of $10-30 \mathrm{~cm}$ gbh was more abundant and formed $57.4 \%$ of the total basal area, which is $4.29 \%$ in SP, while in VP, density is $37.6 \%$ and the basal area is $4.42 \%$ in site VP. In contrast, the tree density and basal area $(31-60 \mathrm{~cm})$ class were greater in VP than in SP. The density of large trees 
Table 3. Species density of trees ( $\geq 10 \mathrm{~cm}$ gbh) in two tropical dry evergreen forest sites (Velleripet - VP and Suryanpet $\mathrm{SP}$ ) on the Coromandel coast of India, arranged in decreasing order of their total abundance and above-ground biomass (AGB).

\begin{tabular}{|c|c|c|c|c|c|c|}
\hline $\begin{array}{l}\text { SI. } \\
\text { No }\end{array}$ & Species name & Family & SP & VP & Total & AGB (kg) \\
\hline 1 & Strychnos nux-vomica L. & Loganiaceae & 0 & 768 & 768 & 268156.31 \\
\hline 2 & Dimorphocalyx glabellus Thw. & Euphorbiaceae & 263 & 0 & 263 & 8792.43 \\
\hline 3 & Lepisanthes tetraphylla (Vahl) Radlk. & Sapindaceae & 117 & 86 & 203 & 232406.92 \\
\hline 4 & Glycosmis pentaphylla (Retz.) DC. & Rutaceae & 84 & 6 & 90 & 737.09 \\
\hline 5 & Azadirachta indica A.Juss. & Meliaceae & 32 & 57 & 89 & 144851.1 \\
\hline 6 & Garcinia spicata (Wight \& Arn.) Hook.f. & Clusiaceae & 28 & 0 & 28 & 50847.44 \\
\hline 7 & Atalantia monophylla DC. & Rutaceae & 16 & 129 & 145 & 21194.02 \\
\hline 8 & Diospyros montana B.Heyne ex A.DC. & Ebenaceae & 15 & 41 & 56 & 7473.85 \\
\hline 9 & Pterospermum canescens Roxb. & Sterculiaceae & 15 & 0 & 15 & 8427.1 \\
\hline 10 & $\begin{array}{l}\text { Tricalysia sphaerocarpa (Dalzell ex Hook.f.) } \\
\text { Gamble }\end{array}$ & Rubiaceae & 15 & 0 & 15 & 1585.64 \\
\hline 11 & Syzygium cumini (L.) Skeels & Myrtaceae & 14 & 0 & 14 & 174190.42 \\
\hline 12 & Memecylon intermedium Blume & Melastomataceae & 13 & 0 & 13 & 5606.82 \\
\hline 13 & Acacia leucophloea (Roxb.) Willd. & Mimosaceae & 0 & 11 & 11 & 2403.14 \\
\hline 14 & Cassia fistula L. & Caesalpiniaceae & 10 & 0 & 10 & 728.2319 \\
\hline 15 & Premna latifolia Roxb. & Verbenaceae & 0 & 10 & 10 & 2347.46 \\
\hline 16 & Albizia amara (Roxb.) Boivin & Mimosaceae & 0 & 9 & 9 & 20003.58 \\
\hline 17 & Barringtonia acutangula (L.) Gaertn. & Baringtoniaceae & 6 & 0 & 6 & 22148.23 \\
\hline 18 & Walsura trifoliolata (A.Juss.) Harms & Meliaceae & 6 & 0 & 6 & 935.29 \\
\hline 19 & Borassus flabellifer $\mathrm{L}$. & Arecaceae & 5 & 16 & 21 & 14509.81 \\
\hline 20 & Cordia dichotoma G.Forst. & Cordiaceae & 5 & 0 & 5 & 5898.56 \\
\hline 21 & Ficus hispida L.f. & Moraceae & 5 & 0 & 5 & 228.57 \\
\hline 22 & Cadaba trifoliata Wight \& Arn. & Capparaceae & 4 & 0 & 4 & 742.62 \\
\hline 23 & Morinda coreia Buch.Ham. & Rubiaceae & 4 & 1 & 5 & 813.43 \\
\hline 24 & Clausena dentata (Willd.) M.Roem. & Rutaceae & 0 & 4 & 4 & 28.23 \\
\hline 25 & Pongamia pinnata (L.) Pierre & Fabaceae & 3 & 0 & 3 & 11799.25 \\
\hline 26 & Alangium salviifolium (L.f.) Wangerin & Cornaceae & 2 & 2 & 4 & 612.29 \\
\hline 27 & Dalbergia paniculata Roxb. & Fabaceae & 2 & 0 & 2 & 850.29 \\
\hline 28 & Streblus asper Lour. & Moraceae & 2 & 0 & 2 & 424.73 \\
\hline 29 & Vitex negundo L. & Verbenaceae & 2 & 0 & 2 & 29.84 \\
\hline 30 & Ehretia pubescens Royle ex Benth. & Boraginaceae & 0 & 2 & 2 & 5323.26 \\
\hline 31 & Prosopis chilensis (Molina) Stuntze & Mimosaceae & 0 & 2 & 2 & 526.08 \\
\hline 32 & Dolichandrone falcata (Wall. ex DC.) Seem. & Bignoniaceae & 0 & 1 & 1 & 1154.15 \\
\hline 33 & Aglaia elaeagnoidea (A.Juss.) Benth. & Meliaceae & 1 & 0 & 1 & 37.15 \\
\hline 34 & Drypetes sepiaria (Wight \& Arn.) Pax \& K.Hoffm. & Ebenaceae & 1 & 3 & 4 & 2351.13 \\
\hline \multirow[t]{2}{*}{35} & Ficus benghalensis L. & Moraceae & 1 & 6 & 7 & 105309.18 \\
\hline & Total & & 671 & 1154 & 1825 & 1126695.81 \\
\hline
\end{tabular}




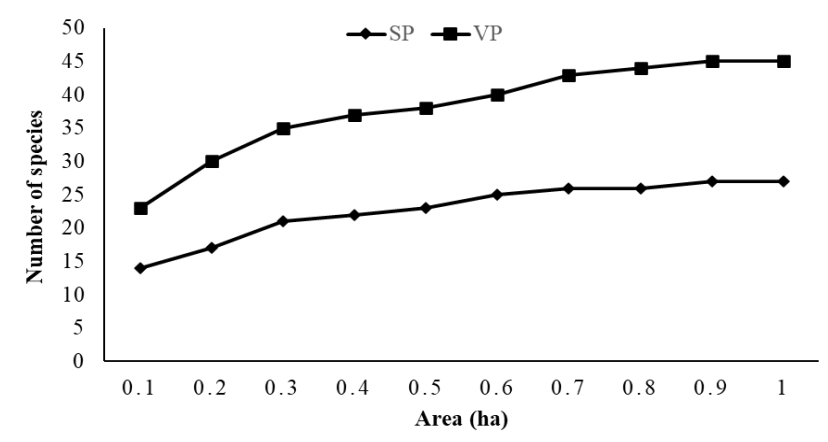

Fig. 2. Species-area curve for the two tropical dry evergreen forest sites - Velleripet (VP) and Suryanpet (SP).

(girth $\geq 210 \mathrm{~cm}$ ) was 23 trees ha ${ }^{-1}$ in SP and 12 in VP. Tree basal area of the larger tree size class (girth $\geq 210$ cm) was $20.1 \mathrm{~m}^{2} \mathrm{ha}^{1}$ in SP and $9.61 \mathrm{~m}^{2} \mathrm{ha}^{1}$ in VP (Fig 3). In both the studied sites, dominant species by girth class varied, D. glabellus and G. pentaphylla notably abundant in lower girth class $(10-30 \mathrm{~cm}$ gbh), whereas middle and higher girth class showed no species. $L$. tetraphylla showed more density in the middle girth class while in the lower and higher moderately distributed site SP. (Fig 4). S. nux-vomica and A. mono phylla most abundant in lower girth class (10-30 cm gbh) $L$. tetraphylla reveal the density in middle girth class while in lower and higher moderately distributed in site VP. (Fig 5).

\section{Species- area curve}

The Species-area curve for the two plots at the 1- ha scale is shown in Fig.2. The observed species accumulation curve for each site captured about $50 \%$ of the species at the 0.2 ha scale and about $80 \%$ at the 0.8 ha scale. It finally reached an asymptote, indicating tree species saturation and sample sufficiency at 1 ha scale.

\section{Above-ground biomass (AGB)}

The total above-ground biomass (AGB) varied among the sites (405.363 Mg/ha in SP) and (721.333 Mg/ha in VP) with the mean value of $563.3 \pm 223.4 \mathrm{Mg} / \mathrm{ha}$. The above-ground C stock was 202.68 and $360.6 \mathrm{Mg} / \mathrm{ha}$ in sites SP and VP, respectively (Table 2). S. nux-

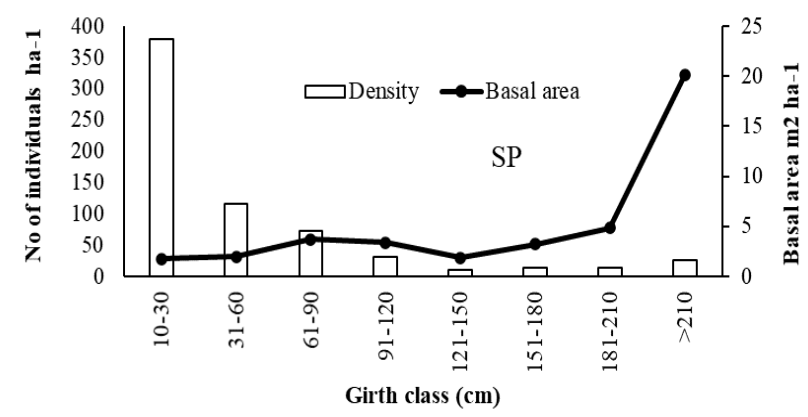

vomica was the top contributor of biomass and $\mathrm{C}$ stocks and contributed $23.8 \%$ of total biomass and $\mathrm{C}$ stocks, respectively, followed by L. tetraphylla (20.7\%), Syzygium cumini (15.4\%). This data was pooled for all sites (Table 3 ). There is a variation in girth class-wise distribution in all the forest types. In SP, AGB increased along with the diameter class, whereas site VP reveal AGB increased in the middle and higher girth class (Fig 6).

\section{DISCUSSION}

Tree diversity, density and girth diameter are vital indicators to assessing the forest above-ground biomass and other ecological processes in tropical forests (Sainge et al., 2020). The tree diversity greatly differs from location to location its mainly due to variation in biogeography, habitat, and disturbance (Neumann and Starlinger, 2001; Padalia et al., 2004; Naidu and Kumar, 2016). Our result revealed tree species diversity represented in site SP (27 species) and VP (18). A number of tree species were recorded in the present study was found to be higher than the number of tree species reported by several researchers in other tropical forests (Fox et al., 1997, 94 species; Kadavul and Parthasarathy, 1999a, 89species; Khera et al., 2001, 92species; Attua and Pabi, 2013, 88 species; Naidu and Kumar, 2016, 129 species; Mohanta et al., 2020, 72 species). Tropical forest showed a wide variation in tree species richness, ranging from 20 species/ ha (low value) in Ngovayang's lowland forests, Cameroon (Gonmadje et al., 2011), to 307 species/ha (high value) in Amazonia Ecuadar (Valencia et al., 1994). Tree species richness, abundance and basal area were higher in the disturbed sites (VP) than the relatively disturbed sites (SP), it coincides with many other studies (Bhuyan et al., 2003; Mishra et al., 2004; Nath et al., 2005; Banda et al., 2006; Muhanguzi et al., 2007; Anitha et al., 2009; Anbarashan and Parthasarathy 2012). Low density and species richness in our SP sites may be due to anthropogenic activities such as collecting fuelwood and fodder and grazing pressure. This scenario leads to thinning the woody layer and changing the forest

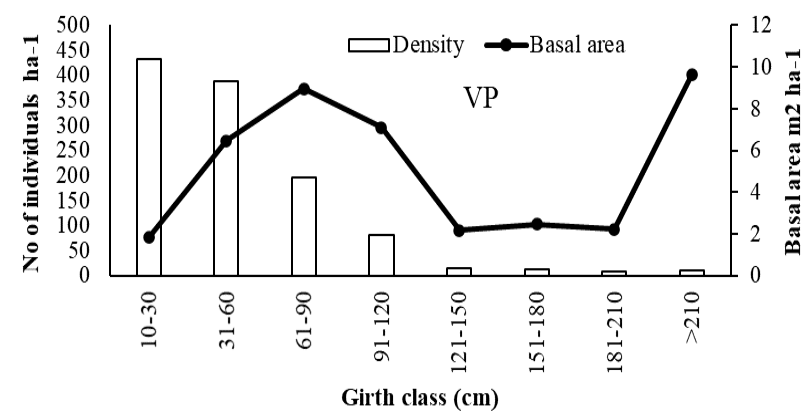

Fig. 3. Tree density $(D)$ and basal area $(B)$ by girth classes in two tropical dry evergreen forest sites - Velleripet (VP) and Suryanpet $(S P)$. 
microclimate, leading to the impaired regeneration process of tree species resulting in low abundance. Tropical dry evergreen forest sites (DTEFs) are smaller in size, ranging from 0.5 to 20 ha, little-known and understudied forest type, protected on religious beliefs, thus gaining significance from ecological and societal perspectives (Anbarashan and Parthasarathy, 2012). The stand density of TDEF is represented by 671 individuals (SP) and 1154 individuals (VP). Tree density is disturbed by various activities like natural calamities, anthropogenic activities, and soil properties. However, our results are comparable with other tropical forests, Kalarayan hills (640-986 stems/ha, Kadavul and Parthasarathy, 1999b), Eastern Ghats (EG) of northern Andhra Pradesh (639-836 stems /ha, Reddy et al., 2011; 435-767 stems/ha, Naidu and Kumar, 2016), Kalakkad, Western Ghats (575-855 stems/ha, Parthasarathy, 1999), Central Himalayan, India (153 to 457 stems /ha, Kaushal and Baishya, 2021), Anamalais (270-673 stems /ha, Ayyappan and Parthasarathy, 1999), Gandhmaran hills, Eastern Ghats (565-671 stems /ha, Sahu et al., 2010), Brazil (420-777 stems / ha, Campbell et al., 1992), Sulawesi (408 stems /ha, Whitmore and Sidiyasa, 1986). Shannon-Weiner values are 2.13 and 1.24 in SP and VP, respectively and others also reported between range 0. 81 and 4.1 (Naidu and Kumar, 2016; Visalakshi, 1995; Sahu et al., 2012; Sundarapandian and Swamy, 2000; Kaushal and Baishya, 2021). The extent of dominance (Simpson's index) in sites SP (4.78) and VP (2.15) in other studies also reported nearby values (Knight, 1975; Visalakshi, 1995; Lalfakwma et al., 2009; Naidu and Kumar, 2016; Mohanta et al., 2020). Our results showed tree species richness and abundance of understory drastically declined with increasing forest disturbance in SP and these results are consistent with other tropical forests (Ramirez-Marcial et al., 2001; Anbarashan and Parthasarathy, 2012). The occurrence of anthropogenic as well as natural disturbances creates conditions for recruitment of new individuals or the growth of preexisting ones in the understory species (Young and Hubbell, 1991; Ramirez-Marcial et al., 2001; Pandian
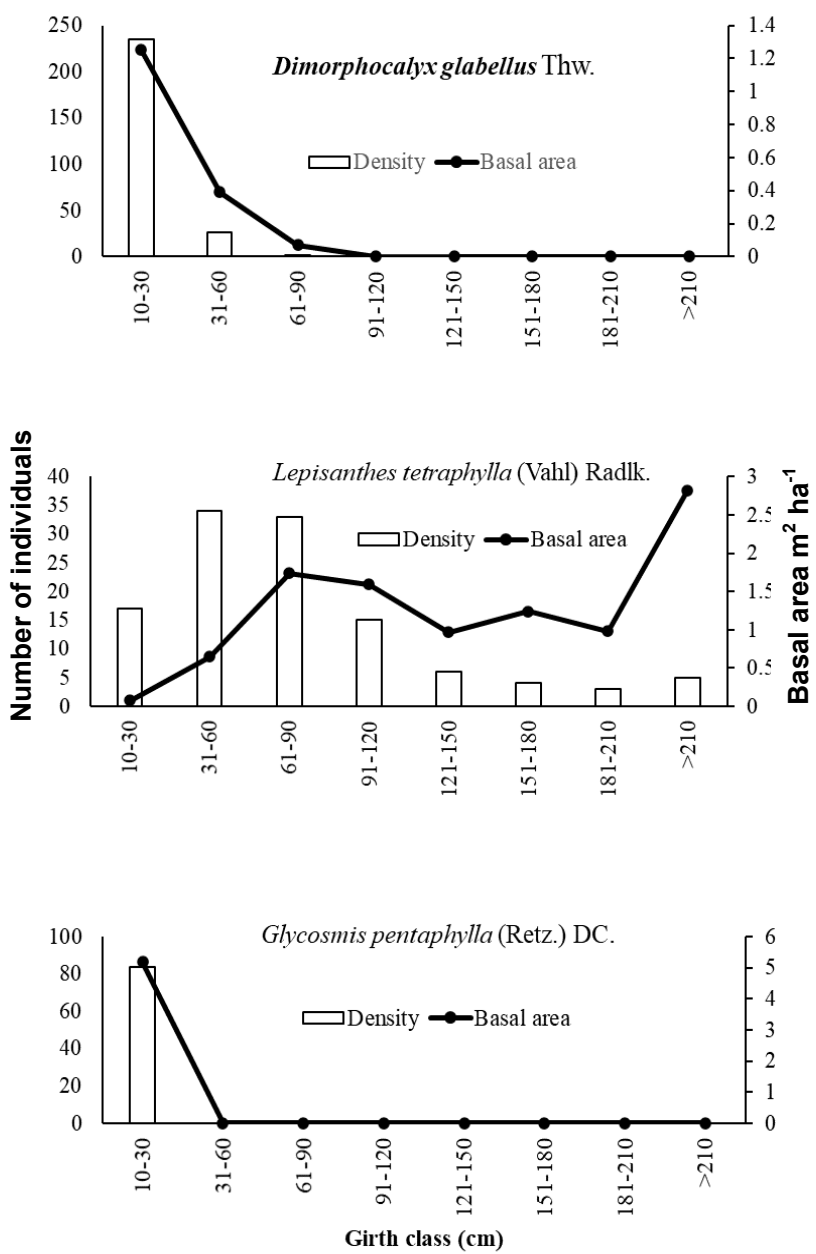

Fig. 4. Girth class distribution of top three abundant tree species in tropical dry evergreen forest sites (Suryanpet - SP) on the Coromandel coast of India.
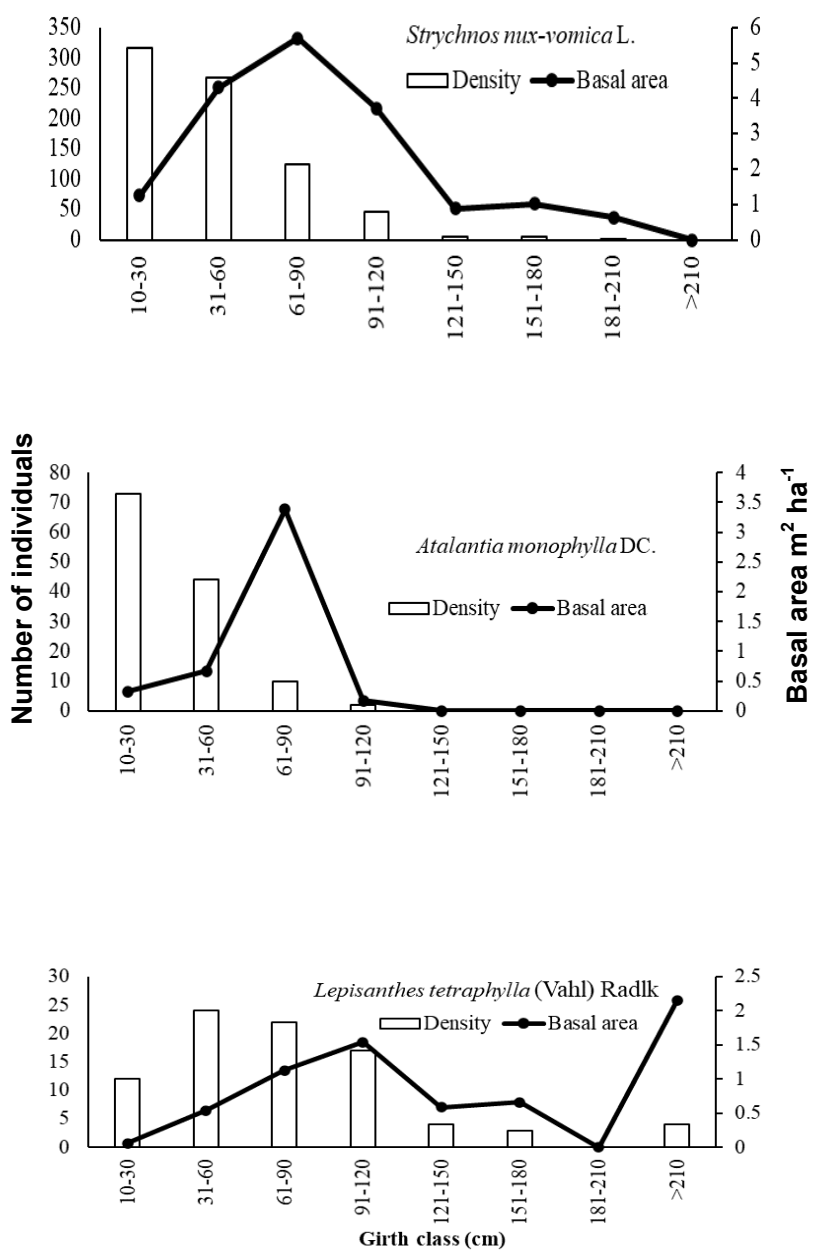

Fig. 5. Girth class distribution of top three abundant tree species in tropical dry evergreen forest sites (Velleripet VP) on the Coromandel coast of India. 
Table 4. Family diversity and density (stems ha ${ }^{-1}$ ), arranged in decreasing order of FIV in two tropical dry evergreen forest sites (Velleripet - VP and Suryanpet - SP).

\begin{tabular}{|c|c|c|c|c|c|}
\hline SI. no. & Family & Genera & Species & Density & FIV \\
\hline 1 & Loganiaceae & 1 & 1 & 768 & 65.14 \\
\hline 2 & Euphorbiaceae & 2 & 2 & 473 & 43.12 \\
\hline 3 & Moraceae & 2 & 3 & 13 & 25.42 \\
\hline 4 & Meliaceae & 3 & 3 & 95 & 22.81 \\
\hline 5 & Rutaceae & 3 & 3 & 237 & 21.40 \\
\hline 6 & Sapindaceae & 1 & 1 & 103 & 20.49 \\
\hline 7 & Mimosaceae & 3 & 3 & 12 & 10.89 \\
\hline 8 & Clusiaceae & 1 & 1 & 28 & 10.68 \\
\hline 9 & Myrtaceae & 1 & 1 & 14 & 10.00 \\
\hline 10 & Ebenaceae & 1 & 1 & 56 & 9.48 \\
\hline 11 & Rubiaceae & 2 & 2 & 20 & 7.20 \\
\hline 12 & Cordiaceae & 2 & 2 & 7 & 6.93 \\
\hline 13 & Verbenaceae & 2 & 2 & 12 & 6.49 \\
\hline 14 & Sterculiaceae & 1 & 1 & 15 & 5.68 \\
\hline 15 & Barrintoniaceae & 1 & 1 & 6 & 5.19 \\
\hline 16 & Arecaceae & 1 & 1 & 21 & 5.18 \\
\hline 17 & Melastomataceae & 1 & 1 & 14 & 4.59 \\
\hline 18 & Fabaceae & 1 & 1 & 1 & 3.66 \\
\hline 19 & Caesalpiniaceae & 1 & 1 & 9 & 3.35 \\
\hline 20 & Capparaceae & 1 & 1 & 4 & 3.24 \\
\hline 21 & Papilionaceae & 1 & 1 & 2 & 3.08 \\
\hline 22 & Alangiaceae & 1 & 1 & 4 & 3.08 \\
\hline 23 & Bignoniaceae & 1 & 1 & 1 & 2.88 \\
\hline
\end{tabular}

and Parthasarathy, 2017).

The basal area of trees $\left(40.71 \mathrm{~m}^{2} /\right.$ ha in SP and 45.46 $\mathrm{m}^{2} /$ ha in VP) in tropical dry evergreen forests are much greater than the range $\left(1.31-13.78 \mathrm{~m}^{2} / \mathrm{ha}\right.$, Sagar and Singh, 2006). Whereas, the present results are less comparable with those reported from New Caledonia (47-49.5 $\mathrm{m}^{2} / \mathrm{ha}$, Jaffre and Veillon, 1990), fan-palm dominated forests of east coast peninsular Malaysia (25.3-48.6 $\mathrm{m}^{2} / \mathrm{ha}$, Nizam et al., 2013). Our results corroborative with other reports, $30.23-32.77 \mathrm{~m}^{2} /$ ha in the tropical moist deciduous forest (Similipal Biosphere Reserve) of India (Mohanta et al., 2020), 7-23 $\mathrm{m}^{2} /$ ha in tropical dry forest communities in India (Jha and Singh, 1990), 10.79-20.44 $\mathrm{m}^{2} /$ ha in tropical dry evergreen forests of southern India (Parthasarathy and Sethi, 1997), Eastern Ghats (EG) of northern Andhra Pradesh (12.98 - $33.63 \mathrm{~m}^{2} / \mathrm{ha}$; Naidu and Kumar, 2016) and 3.9-16.7 $\mathrm{m}^{2}$ /ha in Miombo woodlands, Tanzania (Backeus et al., 2006). Tree density of girth class distribution consistently decreased with increasing size class of trees from 10 to $210 \mathrm{~cm}$ gbh, except for the greatest girth class $\geq$ $210 \mathrm{~cm}$. Whereas basal area of girth class distribution consistently increased with increasing size class of trees from 10 to $210 \mathrm{~cm}$ gbh, except for the girth class $\geq 121$ to $150 \mathrm{~cm}$ in both sites, this result coincides with Pandian and Parthasarathy, (2016a). Tree different frequency classes distribution is commonly used to check forest disturbance effects (Hett and Loucks,
1976; Denslow, 1995; Anbarashan and Parthasarathy; 2012) and detect tree regeneration trends patterns. The frequency of girth class showed that the population structure of trees exhibited in the study plots is in harmony with other tropical forest stands (Bhadra et al., 2010; Sahu et al., 2010). Tree distribution across the different frequency classes showed how well the growing forest utilises functional and structural resources (Naidu and Kumar, 2016). The girth distribution of trees has been often used to represent the population structure of forests (Rao et al., 1990).

In the present study, the above-ground biomass values were $405.3 \mathrm{Mg} / \mathrm{ha}$ in SP and $721.333 \mathrm{Mg} / \mathrm{ha}$ in VP, with the mean value of $563.3 \pm 223.4 \mathrm{Mg} / \mathrm{ha}$. This may be due to the larger stem density and basal area in the forest and also possibly due to domination of $S$. nuxvomica (VP) and $D$. glabellus (SP), which are the members of larger girth classes in the study sites. The present study of AGB values were comparable to the average AGB values of world tropical forests (Malhi et al., 1999; Návar-Chaidez, 2011; Slik et al., 2010; Becknell et al., 2012; Berenguer et al., 2014; Shahid and Joshi, 2015; Behera et al., 2017). The average AGB in the present study was greater in comparison to Amazon forest (288.6 $\mathrm{Mg} \mathrm{ha}^{-1}$; Malhi et al.,1999) but the value was closer to the Bornean (458.1 $\mathrm{Mg} \mathrm{ha}^{-1}$; Silk et al., 2010), African tropical forest (395.7 $\mathrm{Mg} \mathrm{ha}^{-1}$; Lewis et al., 2013), South western Borneo (622 Mg ha ${ }^{-1}$; Paoli 

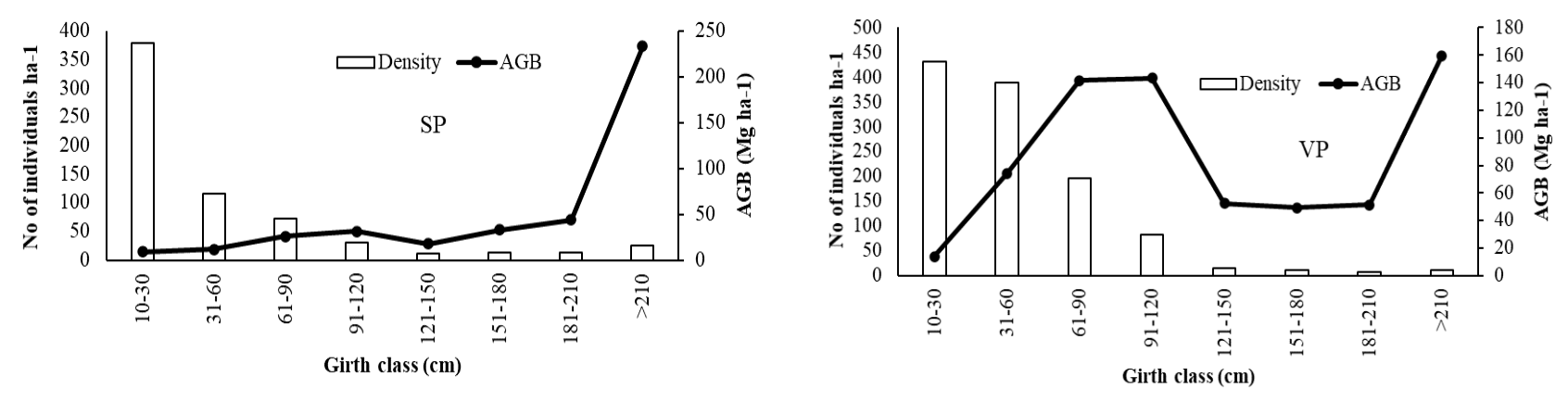

Fig. 6. Above-ground biomass (AGB) and stem density (D) by girth classes in two tropical dry evergreen forest sites Velleripet (VP) and Suryanpet (SP).
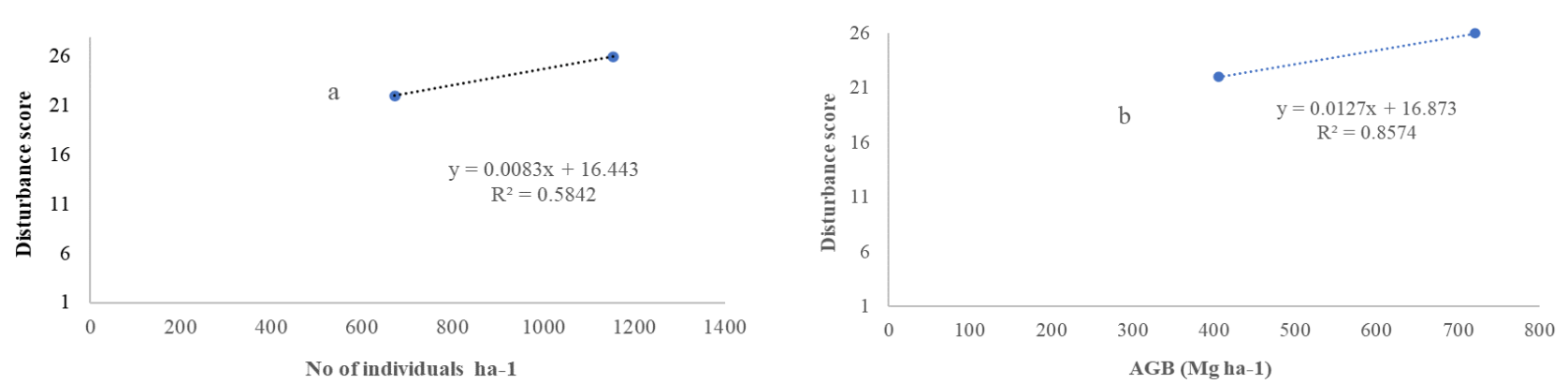

Fig. 7. Correlation between forest site disturbance score and tree density (a) and above-ground biomass (b) in two tropical dry evergreen forest sites - Velleripet (VP) and Suryanpet (SP).

et al., 2007), natural forests of Colombia (Phillips et al., 2016; $226.9 \mathrm{Mg} / \mathrm{ha}^{-1}$ ) and Banja forest in Ethiopia (Abere et al., 2017; $720.6 \mathrm{Mg} / \mathrm{ha}^{-1}$ ). The standing biomass of other Indian tropical moist forests, Western Himalaya (438 Mg ha-1; Shahid and Joshi, 2015), Himalayan foothills (455 $\mathrm{Mg} \mathrm{ha}^{-1}$; Behera et al., 2017), tropical moist deciduous forest (408.39 $\mathrm{Mg} \mathrm{ha}^{-1}$; Mohanta et al., 2020), dry deciduous forest of Eastern Ghats (85.02 to $723.46 \mathrm{Mg} \mathrm{ha}^{-1}$; Gandhi and Sundarpandian, 2017), Mirzapur forest division (244 to $732 \mathrm{Mg} \mathrm{ha}^{-1}$; Singh and Singh, 1991) and moist deciduous forests of Katerniaghat Wildlife Sanctuary, Uttar Pradesh (290.8$455.9 \mathrm{Mg} / \mathrm{ha}^{-1}$; Behera et al., 2017) in India. In this study, the total tree carbon stock was 202.6 and 360.6 $\mathrm{Mg} / \mathrm{ha}$ in sites SP and VP, respectively. This is due to the availability of soil nutrients, moisture content, forest type, slope, precipitation, age and stand girth class. Our results are compared with the tropical dry deciduous forest of India (Raha et al., 2020; 32.7 to $135.1 \mathrm{Mg}$ C/ha), Hays Inlet Conservation Park in Australia (Tran and Dargusch, 2016; 58.5-133.9 Mg C/ha), tropical deciduous forests (Becknell et al., 2012; 39-334 Mg C/ ha), tropical forests (secondary) of southern Mexico (Aryal et al., 2014; 15-123.3 Mg C/ha), in the tropical dry forest (woody species) of India (Chaturvedi et al., 2011; 15.6-151 Mg C/ha). Our results are greater than the reported (Majumdar et al., 2016; 18.9-42.8 Mg C/ ha) in Tripura, India and Silva et al., 2018 reported
(55.91 Mg C/ha) in a seasonal semi-deciduous forest in Minas Gerais, Brazil.

\section{Conclusion}

The present study revealed the relationship between tree variables and anthropogenic disturbances using forest disturbance scores, and it found strong support for tree species richness and forest stand structure are influenced by different levels of human disturbance. Tree species richness was 27 (with dominant species D. glabellus Thw.), and 18 species (with dominant species S. nux-vomica L.) in SP and VP sites respectively. The differences in the edaphic and climatic factors in the study sites might be the reasons for the prevalence of the different dominate species in the study sites. The above-ground biomass values in the present study were $405.3 \mathrm{Mg} / \mathrm{ha}$ in SP and $721.333 \mathrm{Mg} / \mathrm{ha}$ in VP. This may be due to the larger stem density and basal area in the forest and also possibly due to the domination of S. nux-vomica (VP) and D. glabellus (SP), which are the members of larger girth classes in the study sites. Multiple factors threaten the tropical dry evergreen forests (TDEFs) and there is the continuous shrinking of TDEFs due to land-use changes such as expanding agriculture, plantations, and village developmental activities with their restricted geographical distribution. The study also revealed that local people have 
a poor understanding of the ecological impacts of their resource extraction, leading to forest degradation and biodiversity loss. The conservation activities through the ecological restoration of degraded land portions and sacred groves with native species, the help and cooperation of local people are suggested to save these forests and their biodiversity from further degradation.

\section{ACKNOWLEDGEMENTS}

The author E. Pandian thanks Pondicherry University for financial support received through University Grants Commission (UGC) University fellowship.

\section{Conflict of interest}

The authors declare that they have no conflict of interest.

\section{REFERENCES}

1. Abere, F., Belete, Y., Kefalew, A. \& Soromessa, T. (2017). Carbon stock of Banja Forest in Banja district, Amhara region, Ethiopia: An implication for climate change mitigation. Journal of Sustainable Forestry, 36(6), 604-622.

2. Anbarashan, M. \& Parthasarathy, N. (2012). Tree diversity and forest stand structure along disturbance gradients in Indian tropical dry evergreen forest. Ecotropica, 18(2), 119136.

3. Anitha, K., Joseph, S., Ramasamy, E. V., \& Prasad, S. N. (2009). Changes in structural attributes of plant communities along disturbance gradients in a dry deciduous forest of Western Ghats, India. Environmental Monitoring and Assessment, 155(1), 393-405.

4. Armenteras, D., Rodríguez, N. \& Retana, J. (2009). Are conservation strategies effective in avoiding the deforestation of the Colombian Guyana Shield? Biological Conservation, 142(7), 1411-1419.

5. Aryal, D. R., De Jong, B. H., Ochoa-Gaona, S., EsparzaOlguin, L. \& Mendoza-Vega, J. (2014). Carbon stocks and changes in tropical secondary forests of southern Mexico. Agriculture, Ecosystems \& Environment, 195, 220230.

6. Attua, E. M., \& Pabi, O. (2013). Tree species composition, richness and diversity in the northern forest-savanna ecotone of Ghana. Journal of Applied Biosciences, 69, 54375448.

7. Ayyappan, N., \& Parthasarathy, N. (1999). Biodiversity inventory of trees in a large-scale permanent plot of tropical evergreen forest at Varagalaiar, Anamalais, Western Ghats, India. Biodiversity \& Conservation, 8(11), 15331554.

8. Backéus, I., Pettersson, B., Strömquist, L. \& Ruffo, C (2006). Tree communities and structural dynamics in miombo (Brachystegia-Julbernardia) woodland, Tanzania. Forest Ecology and Management, 230(1-3), 171-178.

9. Banda, T., Schwartz, M. W., \& Caro, T. (2006). Woody vegetation structure and composition along a protection gradient in a miombo ecosystem of western Tanzania. Forest Ecology and Management, 230(1-3), 179-185.
10. Becknell, J. M., Kucek, L. K. \& Powers, J. S. (2012). Above-ground biomass in mature and secondary seasonally dry tropical forests: A literature review and global synthesis. Forest Ecology and Management, 276, 88-95.

11. Behera, S. K., Sahu, N., Mishra, A. K., Bargali, S. S., Behera, M. D., \& Tuli, R. (2017). Above-ground biomass and carbon stock assessment in Indian tropical deciduous forest and relationship with stand structural attributes. Ecological Engineering, 99, 513-524.

12. Berenguer, E., Ferreira, J., Gardner, T. A., Aragão, L. E. O. C., De Camargo, P. B., Cerri, C. E. \& Barlow, J. (2014). A large-scale field assessment of carbon stocks in human-modified tropical forests. Global Change Biology, 20(12), 3713-3726.

13. Bhadra, A. K., Dhal, N. K., Rout, N. C. \& Reddy, V. R. (2010). Phytosociology of the tree community of Gandhamardan hill ranges. Indian Forester, 136(5), 610-620.

14. Bhuyan, P., Khan, M. L. \& Tripathi, R. S. (2003). Tree diversity and population structure in undisturbed and human-impacted stands of tropical wet evergreen forest in Arunachal Pradesh, Eastern Himalayas, India. Biodiversity \& Conservation, 12(8), 1753-1773.

15. Brown, S. (1997). Estimating biomass and biomass change of tropical forests: a primer (Vol. 134). Food \& Agriculture Org.

16. Campbell, D. G., Stone, J. L., \& ROSAS JR, A. R. I. T. O. (1992). A comparison of the phytosociology and dynamics of three floodplain (Várzea) forests of known ages, Rio Juruá, western Brazilian Amazon. Botanical Journal of the Linnean Society, 108(3), 213-237.

17. Chaturvedi, R. K., Raghubanshi, A. S. \& Singh, J. S. (2011). Carbon density and accumulation in woody species of tropical dry forest in India. Forest Ecology and Management, 262(8), 1576-1588.

18. Chave, J., Andalo, C., Brown, S., Cairns, M. A., Chambers, J. Q., Eamus, D. \& Yamakura, T. (2005). Tree allometry and improved estimation of carbon stocks and balance in tropical forests. Oecologia, 145(1).

19. Denslow, J. S. (1995). Disturbance and diversity in tropical rain forests: the density effect. Ecological Applications, 5(4), 962-968.

20. Dixon, R. K., Solomon, A. M., Brown, S., Houghton, R. A., Trexier, M. C. \& Wisniewski, J. (1994). Carbon pools and flux of global forest ecosystems. Science, 263(5144), 185190.

21. Fox, B. J., Taylor, J. E., Fox, M. D. \& Williams, C. (1997). Vegetation changes across edges of rainforest remnants. Biological Conservation, 82(1), 1-13.

22. Gandhi, D. S. \& Sundarapandian, S. (2017). Large-scale carbon stock assessment of woody vegetation in tropical dry deciduous forest of Sathanur reserve forest, Eastern Ghats, India. Environmental Monitoring and Assessment, 189(4), 187.

23. Gibson, L., Lee, T. M., Koh, L. P., Brook, B. W., Gardner, T. A., Barlow, J. \& Sodhi, N. S. (2011). Primary forests are irreplaceable for sustaining tropical biodiversity. Nature, 478(7369), 378-381.

24. Gonmadje, C. F., Doumenge, C., McKey, D., Tchouto, G. P., Sunderland, T. C., Balinga, M. P. \& Sonké, B. (2011). Tree diversity and conservation value of Ngovayang's lowland forests, Cameroon. Biodiversity and Conservation, 20(12), 2627-2648. 
Pandian, E. et al. / J. Appl. \& Nat. Sci. 13(3), 981 - 992 (2021)

25. Hett, J. M. \& Loucks, O. L. (1976). Age structure models of balsam fir and eastern hemlock. The Journal of Ecology, 1029-1044.

26. Houghton, R. A. (2005). Tropical deforestation as a source of greenhouse gas emissions Tropical Deforestation and Climate Change Ed. Mutinho and Schwartzman (Belem: IPAM).

27. Iftekhar, M. S. \& Hoque, A. F. (2005). Causes of forest encroachment: An analysis of Bangladesh. GeoJournal, 62(1-2), 95-106.

28. Jaffré, T. \& Veillon, J. M. (1990). Etude floristique et structurale de deux forêts denses humides sur roches ultrabasiques en Nouvelle-Calédonie. Muséum National d'Histoire Naturelle. 12:243e273 [in French].

29. Jha, C. S. \& Singh, J. S. (1990). Composition and dynamics of dry tropical forest in relation to soil texture. Journal of Vegetation Science, 609-614.

30. Kadavul, K. \& Parthasarathy, N. (1999a). Plant biodiversity and conservation of tropical semi-evergreen forest in the Shervarayan hills of Eastern Ghats, India. Biodiversity and Conservation, 8(3), 419-437.

31. Kadavul, K. \& Parthasarathy, N. (1999b). Structure and composition of woody species in tropical semi-evergreen forest of Kalrayan hills, Eastern Ghats, India. Tropical Ecology, 40(2), 247-260.

32. Kaul, M., Mohren, G. M. J. \& Dadhwal, V. K. (2010). Carbon storage and sequestration potential of selected tree species in India. Mitigation and Adaptation Strategies for Global Change, 15(5), 489-510.

33. Kaushal, S. \& Baishya, R. (2021). Stand structure and species diversity regulate biomass carbon stock under major Central Himalayan forest types of India. Ecological Processes, 10(1), 1-18.

34. Khera, N., Kumar, A., Ram, J. \& Tewari, A. (2001). Plant biodiversity assessment in relation to disturbances in midelevational forest of Central Himalaya, India. Tropical Ecology, 42(1), 83-95.

35. Knight, D. H. (1975). A phytosociological analysis of species $\square$ rich tropical forest on Barro Colorado Island, Panama. Ecological Monographs, 45(3), 259-284.

36. Lalfakawma., Sahoo, U.K., Roy, S., Vanlalhriatpuia, K. \& Vanalalhluna, P. C. (2009). Community composition and tree population structure in undisturbed and disturbed tropical semi-evergreen forest stands of North-East India. Applied Ecology and Environmental Research, 7(4), 303-318.

37. Lewis, S. L., Sonké, B., Sunderland, T., Begne, S. K., Lopez-Gonzalez, G., Van Der Heijden, G. M., \& Zemagho, L. (2013). Above-ground biomass and structure of 260 African tropical forests. Philosophical Transactions of the Royal Society B: Biological Sciences, 368(1625), 20120295.

38. Magurran, A.E. 2004. Measuring Biological Diversity. Blackwell, Oxford.

39. Majumdar, K., Choudhary, B. K. \& Datta, B. K. (2016). Above-ground woody biomass, carbon stocks potential in selected tropical forest patches of Tripura, Northeast India. Open Journal of Ecology, 6(10), 598.

40. Malhi, Y., Baldocchi, D. D. \& Jarvis, P. G. (1999). The carbon balance of tropical, temperate and boreal forests. Plant, Cell and Environment, 22(6), 715-740.

41. Metz, B., Davidson, O., Swart, R. \& Pan, J. (Eds.).
(2001). Climate change 2001: mitigation: contribution of Working Group III to the third assessment report of the Intergovernmental Panel on Climate Change (Vol. 3). Cambridge University Press.

42. Mishra, B. P., Tripathi, O. P., Tripathi, R. S. \& Pandey, H. N. (2004). Effects of anthropogenic disturbance on plant diversity and community structure of a sacred grove in Meghalaya, northeast India. Biodiversity and Conservation, 13(2), 421-436.

43. Mohanta, M. R., Mohanta, A., Mohapatra, U., Mohanty, R. C. \& Sahu, S. C. (2020). Carbon stock assessment and its relation with tree biodiversity in Tropical Moist Deciduous Forest of Similipal Biosphere Reserve, Odisha, India. Tropical Ecology, 61(4), 497-508.

44. Muhanguzi, H. D., Obua, J. \& Oryem $\square$ Origa, H. (2007). The effect of human disturbance on tree species composition and demographic structure in Kalinzu Forest Reserve, Uganda. African journal of Ecology, 45, 2-10.

45. Naidu, M. T. \& Kumar, O. A. (2016). Tree diversity, stand structure, and community composition of tropical forests in Eastern Ghats of Andhra Pradesh, India. Journal of AsiaPacific Biodiversity, 9(3), 328-334.

46. Nath, P. C., Arunachalam, A., Khan, M. L., Arunachalam, K. \& Barbhuiya, A. R. (2005). Vegetation analysis and tree population structure of tropical wet evergreen forests in and around Namdapha National Park, northeast India. Biodiversity and Conservation, 14(9), 2109-2135.

47. Návar-Chaidez, J. (2011). The spatial distribution of above -ground biomass in tropical forests of Mexico. Tropical and Subtropical Agroecosystems, 14(1), 149-158.

48. Neumann, M. \& Starlinger, F. (2001). The significance of different indices for stand structure and diversity in forests. Forest Ecology and Management, 145(1-2), 91-106.

49. Nizam, M. S., Jeffri, A. R. \& Latiff, A. (2013). Structure of tree communities and their association with soil properties in two fan-palm dominated forests of east coast Peninsular Malaysia. Tropical Ecology, 54(2), 213-226.

50. Osuri, A. M., Machado, S., Ratnam, J., Sankaran, M., Ayyappan, N., Muthuramkumar, S. \& Naeem, S. (2020). Tree diversity and carbon storage cobenefits in tropical human $\square$ dominated landscapes. Conservation Letters, 13 (2), e12699.

51. Padalia, H., Chauhan, N., Porwal, M. C. \& Roy, P. S. (2004). Phytosociological observations on tree species diversity of Andaman Islands, India. Current Science, 799806.

52. Pandian, E. (2015). Decadal changes in tree and liana diversity and biomass in four inland tropical dry evergreen forests on the Coromandel Coast of India. Thesis pp 1191.

53. Pandian, E. \& Parthasarathy, N. (2016a). Tree Diversity Changes over a Decade (2003-2013) in Four Inland Tropical Dry Evergreen Forest Sites on the Coromandel Coast of India. Journal of Forest and Environmental Science, 32 (2), 219-235.

54. Pandian, E. \& Parthasarathy, N. (2016b). Decadal (20032013) changes in liana diversity, abundance and aboveground biomass in four inland tropical dry evergreen forest sites of peninsular India. Journal of Forestry Research, 27 (1), 133-146.

55. Pandian, E. \& Parthasarathy, N. (2017). Tree growth, mortality and recruitment in four inland tropical dry ever- 
green forest sites of Peninsular India. Biodiversitas Journal of Biological Diversity, 18(4), 1646-1656.

56. Pandian, E. \& Ravichandran, P. (2019). Diversity and Threatened Climber Plants in Tropical Forests of Courtallam Hills, Southern Western Ghats, India. Journal of Tropical Forestry and Environment, 9(2). https:// doi.org/10.31357/jtfe.v9i2.4464

57. Pandian, E. \& Ravichandran, P. (2020). Altitudinal variation of soil organic carbon stock in tropical forest of Courtallam hills, Southern Western Ghats of India. Tropical Plant Research 7(3), 702-714.

58. Paoli, G. D., Curran, L. M. \& Slik, J. W. F. (2008). Soil nutrients affect spatial patterns of above-ground biomass and emergent tree density in southwestern Borneo. Oecologia, 155(2), 287-299.

59. Parthasarathy, N. (1999). Tree diversity and distribution in undisturbed and human-impacted sites of tropical wet evergreen forest in southern Western Ghats, India. Biodiversity and Conservation, 8(10), 1365-1381.

60. Parthasarathy, N. \& Sethi, P. (1997). Trees and liana species diversity and population structure in a tropical dry evergreen forest in south India. Tropical Ecology, 38.

61. Parthasarathy, N., Selwyn, M. A. \& Udayakumar, M. (2008). Tropical dry evergreen forests of peninsular India: ecology and conservation significance. Tropical Conservation Science, 1(2), 89-110.

62. Phillips, J., Duque, Á., Scott, C., Wayson, C., Galindo, G., Cabrera, E. \& Yepes, A. (2016). Live above-ground carbon stocks in natural forests of Colombia. Forest Ecology and Management, 374, 119-128.

63. Phillips, O. L., Malhi, Y., Higuchi, N., Laurance, W. F., Núnez, P. V., Vásquez, R. M. \& Grace, J. (1998). Changes in the carbon balance of tropical forests: evidence from long-term plots. Science, 282(5388), 439-442.

64. Pragasan, L. A. \& Parthasarathy, N. (2010). Landscapelevel tree diversity assessment in tropical forests of southern Eastern Ghats, India. Flora-Morphology, Distribution, Functional Ecology of Plants, 205(11), 728-737.

65. Raha, D., Dar, J. A., Pandey, P. K., Lone, P. A., Verma, S., Khare, P. K. \& Khan, M. L. (2020). Variation in tree biomass and carbon stocks in three tropical dry deciduous forest types of Madhya Pradesh, India. Carbon Management, 11(2), 109-120.

66. Ramírez-Marcial, N., González-Espinosa, M., \& WilliamsLinera, G. (2001). Anthropogenic disturbance and tree diversity in montane rain forests in Chiapas, Mexico. Forest Ecology and Management, 154(1-2), 311-326.

67. Rao, P., Barik, S. K., Pandey, H. N. \& Tripathi, R. S. (1990). Community composition and tree population structure in a sub-tropical broad-leaved forest along a disturbance gradient. Vegetatio, 88(2), 151-162.

68. Reddy, C. S., Babar, S., Amarnath, G. \& Pattanaik, C. (2011). Structure and floristic composition of tree stand in tropical forest in the Eastern Ghats of northern Andhra Pradesh, India. Journal of Forestry Research, 22(4), 491-500.

69. Reichstein, M., Bahn, M., Ciais, P., Frank, D., Mahecha, M. D., Seneviratne, S. I. \& Wattenbach, M. (2013). Climate extremes and the carbon cycle. Nature, 500(7462), 287-295.

70. Sagar, R. \& Singh, J. S. (2006). Tree density, basal area and species diversity in a disturbed dry tropical forest of northern India: implications for conservation. Environmen- tal Conservation, 33(3), 256-262.

71. Sahu, S. C., Dhal, N. K. \& Bhadra, A. K. (2010). Arboreal taxa diversity of tropical forests of Gandhamardan hill range, Eastern Ghats, India: An approach to sustainable biodiversity conservation. Taiwania, 55(3), 208-215.

72. Sahu, S. C., Dhal, N. K., \& Mohanty, R. C. (2012). Tree species diversity and soil nutrient status in a tropical sacred forest ecosystem on Niyamgiri hill range, Eastern Ghats, India. Tropical Ecology, 53, 163-168.

73. Sainge, M. N., Nchu, F., \& Peterson, A. T. (2020). Diversity, above-ground biomass, and vegetation patterns in a tropical dry forest in Kimbi-Fungom National Park, Cameroon. Heliyon, 6(1), e03290.

74. Sapkota, I. P., Tigabu, M. \& Odén, P. C. (2010). Changes in tree species diversity and dominance across a disturbance gradient in Nepalese Sal (Shorea robusta Gaertn. f.) forests. Journal of Forestry Research, 21(1), 25-32.

75. Shahid, M. \& Joshi, S. P. (2015). Biomass and carbon stock assessment in moist deciduous forests of Doon valley, western Himalaya, India. Taiwania, 60(2), 71-76.

76. Silva, H. F., Ribeiro, S. C., Botelho, S. A., Liska, G. R. \& Cirillo, M. A. (2018). Biomass and Carbon in a Seasonal Semideciduous Forest in Minas Gerais. Floresta e Ambiente, 25.

77. Singh, L. \& Singh, J. S. (1991). Species structure, dry matter dynamics and carbon flux of a dry tropical forest in India. Annals of Botany, 68(3), 263-273.

78. Slik, J. F., Arroyo-Rodríguez, V., Aiba, S. I., AlvarezLoayza, P., Alves, L. F., Ashton, P. \& Valencia, R. (2015). An estimate of the number of tropical tree species. Proceedings of the National Academy of Sciences, 112(24), 7472-7477.

79. Slik, J. W. F., Aiba, S. I., Brearley, F. Q., Cannon, C. H., Forshed, O., Kitayama, K. \& van Valkenburg, J. L. (2010). Environmental correlates of tree biomass, basal area, wood specific gravity and stem density gradients in Borneo's tropical forests. Global Ecology and Biogeography, 19(1), 50-60.

80. Sundarapandian, S. M. \& Swamy, P. S. (2000). Forest ecosystem structure and composition along an altitudinal gradient in the Western Ghats, South India. Journal of Tropical Forest Science, 104-123.

81. Tran, D. B. \& Dargusch, P. (2016). Melaleuca forests in Australia have globally significant carbon stocks. Forest Ecology and Management, 375, 230-237.

82. Valencia, R., Balslev, H. \& Miño, G. P. Y. (1994). High tree alpha-diversity in Amazonian Ecuador. Biodiversity and Conservation, 3(1), 21-28.

83. Visalakshi, N. (1995). Vegetation analysis of two tropical dry evergreen forests in southern India. Tropical Ecology, 36(1), 117-127.

84. Vivek, P. \& Parthasarathy, N. (2015). Diversity and carbon stock assessment of trees and lianas in tropical dry evergreen forest on the Coromandel Coast of India. Tropical Plant Research, 2(3), 230-239.

85. Whitmore, T. C. \& Sidiyasa, K. (1986). Composition and structure of a lowland rain forest at Toraut, northern Sulawesi. Kew Bulletin, 747-757.

86. Young, T. P. \& Hubbell, S. P. (1991). Crown asymmetry, treefalls, and repeat disturbance of broad $\square$ leaved forest gaps. Ecology, 72(4), 1464-1471. 